\title{
RADIKAL BEBAS PADA GANGGUAN FUNGSI SENDI RAHANG
}

\author{
Antonia Tanzil \\ Departemen Biologi Oral, Fakultas Kedokteran Gigi, Universitas Indonesia
}

\section{Keywords:}

TMJ dysfunction;

Free radicals

\begin{abstract}
In human, the temporomandibular joint (TMJ) has been proven as a stress-bearing joint, especially during mastication. Overload of shear stress on the joint can cause degenerative diseases of the joint, such as osteoarthrosis or TMJ osteoarthritis (TMJ-OA). Free radicals have been assumed to be associated in the pathogenesis of various degenerative diseases of the joint and oxidative stress is important in the mechanism of TMJ dysfunction. Free radicals are superoxide $\left(\mathrm{O}_{2}{ }^{-}\right)$, hydrogen peroxide $\left(\mathrm{H}_{2} \mathrm{O}_{2}\right)$ and hydroxyl $\left(\mathrm{OH}^{-}\right)$, and are called reactive oxygen species (ROS). Hydroxyl is most destructive in patients with TMJ dysfunction. ROS exert their effects on TMJ by reducing the viscosity of synovial fluid, decreasing joint surface lubrication, breakdown of collagen and proteoglycan, and increasing the activity of cartilage degradation enzymes such as metalloproteinases.
\end{abstract}

\section{Pendahuluan}

Pada manusia, sendi rahang (Temporomandi bular Joint/ TMJ) telah terbukti baik secara klinis maupun eksperimental sebagai sendi yang banyak menerima beban (stress-bearing joint) terutama selama fungsi pengunyahan ${ }^{1,2}$. Gangguan fungsi sendi rahang biasanya disebabkan karena adanya perubahan pada posisi dan atau struktur jaringan di dalam sendi. Pelbagai faktor mekanik dapat menyebabkan terjadinya perubahan dalam struktur sendi rahang meskipun sendi rahang mempunyai kemampuan adaptasi. Misalnya pembebanan yang berlebihan atau tidak seimbang pada sendi akan menyebabkan pembebanan yang berlebihan pada jaringan sendi, akibatnya timbul osteoartrosis atau osteoartritis sendi rahang (TMJ-OA) yaitu penyakit degeneratif sendi yang paling sering menyerang sendi ${ }^{2}$. Faktor mekanik sebagai penyebab osteoartrosis sendi rahang antara lain trauma, parafungsi, oklusi tidak stabil, beban fungsional berlebihan 
dan peningkatan friksi sendi. Faktor-faktor ini dapat terjadi sendiri-sendiri atau saling berhubungan $^{3-6}$.

Seperti disebutkan sebelumnya, TMJ-OA tidak disebabkan oleh radang jadi berbeda dengan rheumatoid arthritis. Proses patologiknya ditandai dengan terjadinya abrasi dan makin memburuknya kartilago sendi disertai dengan penebalan setempat dan remodeling pada tulang sendi ${ }^{7}$. Perubahan perubahan ini sering diikuti dengan reaksi radang sekunder.

Ada dugaan bahwa radikal bebas berperan dalam patogenesis berbagai penyakit degeneratif sendi dan stres oksidatif dapat merupakan aspek penting dalam mekanisme terjadinya gangguan sendi rahang ${ }^{8,9}$. Dalam makalah ini akan dibahas mengenai peran radikal bebas pada gangguan sendi rahang.

\section{Radikal bebas}

Radikal bebas merupakan atom, ion atau molekul yang secara bebas mempunyai satu atau lebih elektron yang tidak berpasangan di orbit luarnya. Radikal bebas ini bersifat sangat aktif, ia akan menyerang molekul di sekitarnya, mengambil elektron untuk mendapatkan konfigurasi elektron yang berpasangan sehingga menjadi kurang aktif. Molekul yang kehilangan satu elektron akan menjadi radikal bebas karena sekarang mempunyai elektron yang tidak berpasangan di kulit luarnya. Selanjutnya radikal bebas yang baru terbentuk akan bereaksi dengan molekul sekitarnya, dan siklus tersebut terulang lagi. Dengan cara ini terjadi reaksi berantai molekuler. Secara teoritis reaksi berantai tersebut akan diteruskan sampai dua radikal bebas saling bereaksi satu sama lain. Bila dua radikal bebas bereaksi satu sama lain, akan terbentuk ikatan kovalen diantara mereka sehingga terbentuk molekul tunggal dengan elektron yang berpasangan. Molekul hibrid ini tidak reaktif lagi seperti radikal bebas karena tidak ada elektron yang tidak berpasangan, dan reaksi berantai tersebut akan berhenti ${ }^{10}$.

Dalam keadaan fisiologik normal, radikal bebas dapat berfungsi sebagai messenger kedua dengan mengaktifkan fungsi sel, seperti katabolisme asam arahidonat $^{11}$, pergantian matriks ekstraseluler ${ }^{12}$ dan pengaturan berbagai ekspresi gen ${ }^{13}$. Akumulasi radikal bebas yang berlebihan dalam jaringan akan menimbulkan keadaan patologik yaitu rusaknya molekul ekstraseluler dan intraseluler dan juga aktivasi berlebihan proses seluler ${ }^{14-22}$. Keadaan yang mengakibatkan terjadinya penumpukan radikal bebas dalam suatu jaringan dinamakan stres oksidatif. Dalam kehidupan manusia sumber utama radikal bebas adalah oksigen ${ }^{23}$. Termasuk dalam radikal bebas adalah superoksida $\left(\mathrm{O}_{2}^{-}\right)$, hydrogen peroksida $\left(\mathrm{H}_{2} \mathrm{O}_{2}\right)$ dan radikal hidroksil $\left(\mathrm{OH}^{-}\right)^{24}$. Meskipun radikal bebas berguna dalam kehidupan, tetapi dapat sangat berbahaya untuk jaringan bila kegiatannya tidak terkontrol yaitu merusak molekul selular maupun ekstraselular. Untuk mengendalikan kerusakan akibat radikal bebas, terdapat berbagai enzim dalam jaringan tubuh yang berfungsi mengubah radikal bebas yang sangat reaktif menjadi molekul yang kurang aktif yaitu enzim dismutase superoksid, katalase dan peroksidase. Di samping itu, antioksidan dengan berat molekul rendah seperti glutation, asam urat, tokoferol, askorbat, dan beberapa hormon misalnya melatonin, 'menyapu bersih' radikal bebas saat mereka terbentuk dalam jaringan dengan metabolisme aktif ${ }^{25}$. Pada keadaan normal, terdapat keseimbangan antara pembentukan radikal bebas dan 'pembersihan' radikal bebas. Jadi penumpukan radikal bebas yang disertai dengan defisiensi 'pembersih' radikal bebas dalam TMJ akan menyebabkan kerusakan jaringan, yang selanjutnya menimbulkan gangguan fungsi TMJ.

\section{Pembentukan radikal bebas dalam TMJ}

Radikal bebas dapat terbentuk dalam TMJ melalui beberapa cara yaitu pertama: trauma mekanik langsung pada jaringan sendi, kedua: luka reperfusi-hipoksia, dan ketiga katabolisme asam arahidonik. Orang belum banyak mengetahui mengenai sifat stres mekanik yang terjadi pada TMJ manusia pada waktu rahang digerakkan. Terakhir ada anggapan bahwa stres mekanik pada TMJ manusia sama seperti pada sendi lain misalnya lutut dan pinggul. 
Stres mekanik ini ternyata dapat mengurai ikatan kovalen dalam molekul dan akan membentuk radikal bebas ${ }^{25}$.

Pencatatan tekanan dalam sendi rahang pada waktu clenching volunter menunjukkan terjadi peningkatan tekanan dalam sendi antara 8 sampai $200 \mathrm{mmHg}$ ( rata-rata $63,90 \pm 52.25$ $\mathrm{mmHg}$ ). Bila tekanan dalam sendi lebih dari 40 $\mathrm{mmHg}$, akan menekan arteriolar perifer sehingga menyebabkan hipoksia sementara yang akan diikuti oleh reoksigenisasi pada waktu clenching dihentikan ${ }^{26}$. Ternyata jika stres mekanik menekan jaringan vaskuler pada TMJ dengan articular disc displacement, stres tersebut menjadi lebih besar daripada tekanan darah kapiler jaringan tersebut. Dengan adanya reperfusi-hipoksia akan terbentuk radikal bebas karena tekanan dalam sendi yang tidak adekuat. Terjadinya hipoksia menyebabkan populasi sel-sel setempat berubah metabolismenya yang dapat menimbulkan pembentukan radikal bebas bila perfusi dilakukan kembali ${ }^{16}$. Bila sendi istirahat dan jaringan sendi di reperfusi, xantine oxidase dapat bereaksi dengan tumpukan hipoxanthine atau xanthine, dan dengan adanya oksigen akan membentuk anion superoksid radikal $\left(\mathrm{O}_{2}^{-{ }^{-}}\right)$. Anion superoksid radikal kemudian bereaksi dengan hydrogen peroksid $\left(\mathrm{H}_{2} \mathrm{O}_{2}\right)$ membentuk anion hidroksil yang sangat reaktif.

\section{Pembentukan radikal bebas pada eksperimen induksi artritis TMJ}

Stres mekanik pada TMJ dapat menyebabkan terbentuknya reactive oxygen species (ROS) atau radikal bebas yang terdiri atas superokside, hydrogen peroksida dan radikal hidroksil. ROS ini dapat menyebabkan degradasi hialuronan dan peningkatan friksi dalam sendi yang akan memicu reaksi radang dengan akibat peningkatan permeabilitas pembuluh darah, infiltrasi netrofil dan makrofag ke dalam sendi. Peningkatan netrofil atau makrofag dalam sinovial yang meradang akan mengakibatkan pembentukan oksidan dan radikal bebas yang kemudian dapat menimbulkan radang sendi lebih lanjut ${ }^{1}$.
ROS dalam Interleukin 1 (IL-1) cairan sinovial dapat diidentifikasi dengan mudah pada induksi artritis TMJ tikus ${ }^{27}$. Radikal hidroksil (HO) kemungkinan besar merupakan oksigen intermediate dalam jaringan dan atau sel yang rusak dan terbentuk dari ion-ion besi $\left(\mathrm{Fe}^{2+}\right.$ dan $\mathrm{Fe}^{3+}$ ), yang berasal dari denaturasi hemoglobin dalam perfusat cairan sinovial artritik. Ion-ion besi tersebut akan merangsang reaksi katalitik (Fenton reaction) untuk membentuk radikal $\mathrm{HO}, \mathrm{R}$, dan $\mathrm{H}^{.28,29}$. Yang menarik adalah, IL-1 dan Tumor Necrotising Factor (TNF $\alpha)$ ternyata meningkatkan penglepasan $\mathrm{O}_{2}{ }^{\circ}$ dari kultur khondrosit dan sel-sel sinovial sehingga merusak DNA ${ }^{30}$. Baik penghambatan sintesis asam hialuronik maupun aktivasi proteinase yang mendegradasi matriks ekstraseluler kartilago sendi disebabkan oleh $\mathrm{O}_{2}{ }^{31}$. Sitokin sebagai penyebab radang (proinflammatory), IL-1 dan TNF $\alpha$ akan merangsang katabolisme asam arahidonik dan menginduksi pembentukan ROS. Hal ini menunjukkan bahwa ROS dapat menyebabkan radang sendi, dan ada kemungkinan bahwa radang mempercepat pembentukan ROS sehingga mengakibatkan komponen-komponen sendi berdegenerasi ${ }^{32,33}$.

\section{Pembentukan radikal bebas pada penyakit sendi}

Nitrit oksida (NO) adalah radikal bebas yang berbentuk gas, disintesis dari L-arginin oleh nitrit oksida sintase (NOS) dan berperan penting dalam mengatur fungsi sendi ${ }^{34}$. Pada awalnya NO ditemukan sebagai faktor relaksasi yang berasal dari endotelium, berfungsi mengatur tekanan darah, tonus vaskuler, dan memicu impuls saraf (neural signaling). NO dapat bereaksi dengan superoksida $\left(\mathrm{O}_{2}{ }^{\circ}\right)$ membentuk peroksinitrit oksidan yang poten (ONOO) dan radikal hidroksil, serta keduanya dapat ditemukan dalam jejas seluler ${ }^{35,36}$.

Telah diperkirakan bahwa radikal bebas yang paling merusak yaitu radikal hidroksil (HO) yang terdapat dalam cairan sinovial TMJ dengan ID (Internal derangement) dan OA. Pada semua penderita, ternyata pembentukan HO secara efektif dihambat oleh khelator ion deferoksamin (DFX), ini berarti bahwa ion besi 
sangat mempengaruhi produksi $\mathrm{HO}$ seperti telah dilaporkan pada arthritis tikus ${ }^{27}$. Dari hasil penelitian ini dianggap bahwa $\mathrm{HO}$ yang terbentuk melalui reaksi Fenton pada peradangan TMJ dapat berkembang menjadi gangguan fungsi TMJ. Peningkatan pembentukan $\mathrm{HO}$ pada TMJ artritik menunjukkan adanya akumulasi $\mathrm{H}_{2} \mathrm{O}_{2}$ akibat dismutasi $\mathrm{O}_{2} \cdot$ jaringan dan atau SOD (superoxide dismutase) ekstraseluler dalam perfusat cairan sinovial.

\section{Perusakan molekul dan gangguan fungsi TMJ oleh spesies oksigen reaktif (ROS)}

Radikal bebas mempengaruhi sistem molekuler TMJ dan memperburuk fungsi TMJ. Pertama ia mereduksi viskositas cairan sinovial melalui depolimerisasi dan/atau konfigurasi molekuler asam hialuronik $(\mathrm{HA})^{12}$; kedua mereduksi lubrikasi permukaan sendi karena memburuknya permukaan lapisan fosfolipid aktif (SAPL), yang bekerja sebagai pelumas dan pelindung permukaan sendi yang sangat efisien ${ }^{6}$; ketiga mengurai kolagen dan $\operatorname{proteoglikan}^{37}$, dan keempat menggiatkan enzim-enzim degradasi kartilago misalnya matriks metaloproteinase. Radikal hidroksil bereaksi dengan lipid membran untuk memulai rangkaian reaksi auto-oksidasi yang akhirnya dapat mengakibatkan pembentukan radikal carbon-centered (R), alkoksil (RO), dan peroksil (ROO). Kesemuanya ini merupakan petanda peroksidasi lipid dan pemutusan homeostasis seluler. Nitzan menyatakan bahwa lisis lapisan SAPL oleh fosfolipase A2 (sPLA2) bersama dengan depolimerisasi HA yang disebabkan oleh radikal-radikal bebas dapat mengakibatkan memburuknya lubrikasi permukaan sendi, sehingga berlanjut menjadi internal derangement (ID) $\mathrm{TMJ}^{6}$. Data ini menunjukkan bahwa radikal bebas dapat menyebabkan memburuknya molekul, yang kemudian berlanjut pada perubahan-perubahan degeneratif dalam TMJ

\section{Kesimpulan}

- Radikal bebas dan enzim-enzim antioksidan ada hubungannya dengan patogenesis penyakit degeneratif sendi dan stres oksidatif merupakan aspek penting pada mekanisme terjadinya gangguan sendi rahang.

- Radikal hidroksil, adalah oksigen yang paling besar kemungkinannya terlibat langsung dalam kerusakan jaringan, telah terbukti dengan ditemukannya pada penyakit TMJ. Ion-ion besi bebas $\left(\mathrm{Fe}^{2+}\right.$ dan $\left.\mathrm{Fe}^{3+}\right)$, yang mungkin berasal dari hemoglobin pada TMJ artritik, ada kemungkinan berperan sebagai penyebab terjadinya reaksi katalitik dalam pembentukan radikal HO; R; dan $\mathbf{H}$.

\section{Daftar Pustaka}

1. Tomida M,Ishimaru J, Mizui T. Mechanical Stress and Oxidative Stress as Aetiological Factors for Temporomandibular Joint Disorders. A theoretical Concept. Hosp Dent Oral-Maxillofac Surg 2004; 16 (1):23-27.

2. Tanaka E, Detamore MS, Mercuri LG. Degenerative Disorders of the Temporomandibular Joint: Etiology, Diagnosis and Treatment. J Dent Res 2008; 87(4):296-307.

3. Stegenga B, De Bont LGM, Boering G. Osteoarthrosis as the cause of craniomandibular oain and dysfunction: a unifying concept. J Oral Maxillofac Surg 1989; 47: 249-256.

4. Arnett GW, Milam SB, Gottesman L. Progressive mandibular retrusion-idiopathic condylar resorption. Part 1.Am J Orthod Dentofacial Orthop 1996a; 110:8-15.

5. Arnett GW, Milam SB, Gottesman L. Progressive mandibular retrusion-idiopathic condylar resorption. Part II..Am J Orthod Dentofacial Orthop 1996b; 110:117-127.

6. Nitzan DW. The process of lubrication impairment and its involvement in temporomandibular joint disc displacement: 
a theoretical concept. J Oral Maxillofac Surg 2001; 59:36-45.

7. Zarb GA, Carlsson GE. Temporomandibular disorders: osteoarthritis. J Orofac Pain 1999; 13:295306.

8. Milam SB, Zardeneta G, Schmitz JP. Oxidative stress and degenerative temporomandibular joint disease: A proposed hypothesis. J Oral Maxillofac Surg 1998; 56:214-223.

9. Milam SB, Schmitz JP. Molecular Biology of temporomandibular joint disorders: proposed mechanisms of disease. J Oral Maxillofac Surg 1995;53:1448-1454.

10. Halliwell B, Gutteridge JMC. Free radicals in Biology and Medicine. Dalam: Kubota E et al. Oxidative Stress and Temporomandibular Dysfunction. Bull.Kanagawa dent.Col 2002; 30 (2): 141-145.

11. Kanner J, Harel S, Granit R. Nitric Oxide, an inhibitor of lipid oxidation by lipoxygenase, cyclooxygenase and hemoglobin. Dalam: Kubota $E$ et al. Oxidative Stress and Temporo-mandibular Dysfunction. Bull.Kanagawa dent.Col 2002; 30 (2): 141-145.

12. Saari H, Suomalainen K, Lindy et al. Activation of latent human neutrophil collagenase by reactive oxygen species and serine proteases. Dalam: Kubota E et al. Oxidative Stress and Temporo-mandibular Dysfunction. Bull.Kanagawa dent.Col 2002; 30 (2): 141-145.

13. Siebenlist U, Franzoso G, Brown K. Structure, regulation and function of NFkB. Anпи Rev Cell Biol 1994; 10: 405-455.

14. Mc Cord JM. Free radicals and inflammation: protection of synovial fluid by superoxide dismutase. Science 1974; 185: 529-531.

15. Hertz F, Cloarec A. Pharmacology of free radicals: Recent views on their relation to inflammatory mechanisms. Dalam: Kubota E et al. Oxidative Stress and Temporomandibular Dysfunction. Bull.Kanagawa dent.Col 2002; 30 (2): 141-145.

16. Mc Cord JM. Oxygen-derived free radicals in postischemic tissue injury. $N$ Engl J Med 1985; 312:159-163.

17. Blake DR, Merry $\mathrm{P}$, Unsworth $\mathrm{J}$ et al. Hypoxic-reperfusion injury in the inflamed human joint. Lancet 1989; 1:289-293.
18. Uchida K, Kato Y, Kawakishi S. A novel mechanism for oxidative cleavage of propyl peptides induced by the hydroxyl radical. Biochem Biophys Res Comm 1990; 169: 265-271.

19. Greenwald RA. Oxygen radicals, inflammation, and arthritis: Pathophysiological considerations and implications for treatment. $\mathrm{J} \mathrm{Biol} \mathrm{Chem}$ $1991 ; 20: 219-240$.

20. Stadman ER, Berlett BS. Fenton chemistry: Amino acid oxidation. J Biol Chem 1991; 266:17201-17211.

21. Zardeneta G, Milam SB, Schmitz JP. Irondependent generation of free radicals: plausible mechanismus in theprogressive deterioration of the temporomandibular joint. J Oromaxillofac Surg 2000; 58:302308.

22. Milam SB, Zardeneta G, Schmitz JP. Oxidative stress and degenerative temporomandibular joint disease: a proposed hypothesis.J Oral maxillofac Surg 1998; 56:214-223.

23. Heng-X $\mathrm{C}$ et al. Free-radical Oxidation and Superoxide Dismutase Activit in Synovial Fluid of Patients with Temporomandibular Disorders. J of Orofac Pain 2006; 20(1) 5358.

24. Chismirina S, Ibrahim EA. Aspek Molekular Penuaan:Pengaruh Stres Oksidatif Akibat Radiasi Ion terhadap Mitokondria, Telomer dan Sistem Kekebalan Tubuh. IJD 2006: 13(2):8489.al

25. Kubota E, Suga M, Shimizu $S$, et al. Oxidative Stress and Temporo-mandibular Dysfunction. Bull Kanagawa Dent Col 2002; 30 (2) 141-145.

26. Nitzan DW. Intraarticular pressure in the functioning human temporomandibular joint and its alteration by uniform elevation of the occlusal plane. J Oral Maxillofac Surg 1994; 52: 671-679.

27. Kawai Y, Kubota E, Okabe E. Reactive oxygen species participation in experimentally induced arthritis of the temporomandibular joint in rats. $J$ Dent Res 2000; 79(7): 1489-1495.

28. Baker MS. Free radicals and connective tissue damage, in Rice-Evans CA, Burdon RH (eds): Free Radical Damage and Its Control. . Dalam: Kubota E et al. Oxidative Stress and Temporo-mandibular 
Dysfunction. Bull.Kanagawa dent.Col 2002; 30 (2): 141-145.

29. Gutteridge JMC. Iron promoters of the Fenton reaction and lipid peroxidation can be released from haemoglobin by peroxides. Dalam: Kubota E et al. Oxidative Stress and Temporo-mandibular Dysfunction. Bull.Kanagawa dent.Col 2002; 30 (2): 141145.

30. Ahmadzadeh N, Shingu M, Nobunaga M. The Effect of recombinant tumor necrosis factor-alpha on superoxide and metalloproteinase production by synovial cell and chondrocytes. Dalam: Kubota E et al. Oxidative Stress and Temporomandibular Dysfunction. Bull.Kanagawa dent. Col 2002; 30 (2): 141-145.

31. Fukuda K, Takayama M, Ueno $\mathbf{M}$ et al. Hyaluronic acid inhibits interleukin-1induced superoxide anion in bovine chondrocytes. Inflamm Res 1997; 46: 114117.

32. Kubota E, Imamura $\mathrm{H}$, Kubota $\mathrm{T}$ et al.Interleukin 1 and stromelysin (MMP3) activity of synovial fluid as possible markers of osteoarthritis in the temporomandibular joint. J Oral Maxillofac Surg 1997; 55: 20-27.
33. Kubota E, Kubota T, Matsumoto J et al. Synovial fluid cytokines and proteinases as markers of temporomandibular joint disease. J OralMaxillofac Surg 1998; 56: 192-198.

34. Moncada S, Palmer RMJ , Higgs AE. Nitric Oxide: Physiology, pathology , pathophysiology and pharmacology. Pharmacol Rev 1991; 43: 109-142.

35. Beckman JS, Beckman TW, Chen J et al. Apparent hydroxyl radical production by peroxynitrite: implications for endotherial injury from nitric oxide and superoxide. Dalam: Kubota E et al. Oxidative Stress and Temporo-mandibular Dysfunction. Bull.Kanagawa dent.Col 2002; 30 (2): 141145.

36. Stamler JS, Singel DJ, Loscalzo J. Biochemistry of nitric oxide and its redoxactivated forms. Science 1992; 258: 18981902.

37. Roberts CR, Roughley PJ, Mort JS. Degradation of human proteoglycan aggregate induced by hydrogen peroxide. Protein fragmentation, amino acid modification and hyaluronic acid cleavage. J Biochem 1989; 259: 805-811. 